\title{
Mechanisms Underlying Regional Differences in Lipolysis in Human Adipose Tissue
}

\author{
Hans Wahrenberg, Fredrik Lönnqvist, and Peter Arner \\ Department of Medicine, Huddinge Hospital, S-14186 Huddinge, Sweden
}

\begin{abstract}
Catecholamine-induced lipolysis was investigated in nonobese females and males. Isolated subcutaneous adipocytes were obtained from the abdominal and gluteal regions. The lipolytic effect of noradrenaline was four to fivefold more marked in abdominal adipocytes than in gluteal fat cells. This regional difference was more apparent in females than in males. No site differences were observed when lipolysis was stimulated with agents acting at different postreceptor levels. The beta-adrenergic lipolytic sensitivity was 10-20 times greater in abdominal adipocytes from both sexes than in gluteal adipocytes. Abdominal adipocytes from females showed a 40 times lower alpha adrenergic antilipolytic sensitivity than did gluteal adipocytes, but the adenosine receptor sensitivity was similar in both sites. Beta-receptor affinity for agonists displayed no site or sex variation. Abdominal adipocytes showed a twofold increased betaadrenoceptor density than did gluteal cells from both sexes. The alpha $a_{2}$-adrenoceptor density was similar in all regions, but in females the affinity of clonidine for these sites was 10-15 times lower in the abdominal fat cells compared with gluteal cells.

In conclusion, regional differences in catecholamine-induced lipolysis are regulated at the adrenoceptor level, chiefly because of site variations in beta-adrenoceptor density. Further variations in the affinity properties of alpha $a_{2}$-adrenergic receptor in females may explain why the regional differences in catecholamine-induced lipolysis are more pronounced in women than in men.
\end{abstract}

\section{Introduction}

It is well established that abdominal adipocytes are more responsive to catecholamines than are femoral and gluteal adipocytes (1-5). This discrepancy is even more pronounced during fasting (6). Moreover, men and women have typically different body fat distributions, men being prone to accumulate fat in the abdominal region, and women accumulating fat mainly in the gluteal-femoral regions. Only the abdominal type of obesity has been associated with a higher risk of cardiovascular morbidity $(7,8)$ and metabolic aberrations, such as

Presented in part at the 1st European Symposium on Obesity in Stockholm, 5-6 June 1988.

Address reprint requests to Dr. Hans Wahrenberg, Department of Medicine, Huddinge Hospital, S-14186 Hudding, Sweden.

Received for publication 18 November 1988 and in revised form 29 March 1989.

J. Clin. Invest.

(C) The American Society for Clinical Investigation, Inc.

0021-9738/89/08/0458/10 \$2.00

Volume 84, August 1989, 458-467 diabetes mellitus and hyperlipidemia $(9,10)$. This suggests that human adipose tissue, from a functional point of view, is not a uniform tissue. It shows marked regional differences in metabolic activity that may be influenced by sex factors. This may be of pathophysiological importance for the development of different types of regional obesity as well as for complications arising from an excess of body fat. The factors responsible for fat localization in the upper or lower parts of the body and for the association of regional adiposity with morbidity are unknown, but differences in the control of the adipose tissue lipolysis may play a role. During lipolysis, triglycerides in fat cells are hydrolyzed to glycerol and free fatty acids. Because $>95 \%$ of the adipocyte volume consists of triglycerides, it is possible that factors governing the synthesis and breakdown of the triglycerides are of importance for adiposity. In adult man catecholamines and insulin are the only hormones with a marked effect on lipolysis (11). Furthermore, in humans, unlike most other species, catecholamines have dual effects on the lipolysis rate, both accelerating through beta-adrenoceptors and retarding through alpha $a_{2}$-adrenoceptors $(12,13)$.

The mechanisms underlying regional differences in catecholamine effects on lipolysis are unknown. Differences in the functional balance between alpha- and beta-mediated effects at the level of one or both of the two adrenoceptor subtypes may account for the heterogeneity of catecholamine-stimulated lipolysis between fat depots. Site differences may also be localized at any link in the chain of postreceptor events that transfers the signal from the adrenoceptors to the hormonesensitive lipase. The influence of sex on site differences in lipolysis is also unclear. In this study, the adrenergic control of lipolysis was investigated in abdominal and gluteal adipocytes from nonobese men and women. Adrenoceptor status and lipolysis were assessed under identical conditions in intact fat cells. This was achieved by radioligand binding techniques using agonists and antagonists, as well as by lipolysis experiments with selective adrenergic agonists. The importance of postreceptor events was investigated using lipolytic agents that act at well-defined postreceptor steps.

\section{Methods}

Subjects. 30 male and 27 female healthy volunteers participated in this study. They were all drug free and no one in the female group took oral contraceptives over the last $6 \mathrm{mo}$. The age of the male group was 25-58 yr (mean \pm SE: $34.3 \pm 1.8 \mathrm{yr}$ ); age of the female group was 24-55 yr (mean \pm SE: $32.8 \pm 1.8 \mathrm{yr}$ ). Two women were postmenopausal but all other women had regular menstruation cycles. All were of normal weight and the body mass index was $22.8 \pm 0.4$ and $22.7 \pm 0.4 \mathrm{~kg} / \mathrm{m}^{2}$ in the two groups, respectively. The proportion of body fat assessed by four different caliper measurements of skinfold thickness (umbilical, scapular, biceps, triceps) was $32.6 \pm 1.3 \%$ in the female group and $23.1 \pm 1.1 \%$ in the male group, respectively $(P<0.0001)$. The waist to hip ratio was $0.911 \pm 0.013$ and $0.945 \pm 0.008$ in the female and male group, respectively $(P<0.02)$. All subjects gave their informed consent 
and the study was approved by the Ethics Committee of the Karolinska Institute. After the subjects had an overnight fast, one subcutaneous fat specimen was excised from the infraumbilical region (abdominal site) and one from the upper lateral quadrant of the gluteal region, using prilocaine chloride as the local anesthetic agent. Local anesthesia was given in such a way that it did not influence the experiments on the excised adipose tissue (14). It was not possible to perform all types of experiments in adipose tissue from the same donor, because for ethical reasons, only $2-4 \mathrm{~g}$ of adipose tissue could be excised.

Isolation of adipocytes. Fat cells were isolated as described previously (15), using a modification of Rodbell's method (16).

Receptor binding assays. The incubations were carried out under steady-state conditions, as described in detail elsewhere $(6,17)$. Briefly, $\sim 2 \times 10^{4}$ fat cells were incubated in triplicate at $37^{\circ} \mathrm{C}$ in $1 \mathrm{ml}$ of Krebs-Ringer-phosphate (KRP) ${ }^{1}$ buffer (pH 7.4) containing $5 \mathrm{~g} /$ liter $\mathrm{BSA}, 1 \mathrm{~g} /$ liter glucose, and $0.1 \mathrm{~g} /$ liter ascorbic acid, plus radioligands with and without unlabeled adrenergic antagonist.

In the experiments where antagonist binding sites were determined, one high and one low concentration of radioligand were used in all subjects. It was not possible to perform complete saturation experiments in all subjects because the amounts of adipose tissue available were limited. However, in three male and three female subjects complete saturation experiments were performed for both the beta- and the alpha ${ }_{2}$-receptors. $\left[{ }^{3} \mathrm{H}\right.$ ]yohimbine was used as the alpha $a_{2}$-adrenoceptor ligand. The hydrophobic antagonist ${ }^{125} \mathrm{I}$-cyanopindolol ( $\left.{ }^{125} \mathrm{ICYP}\right)$ and the hydrophilic antagonist $( \pm)-4$ (3-butylamino-2-hydroxypropoxy)$\left(5,7-{ }^{3} \mathrm{H}\right)$-benzimidazole-2-1-hydrochloride $\left(\left[{ }^{3} \mathrm{H}\right] \mathrm{CGP}\right)$ were used as the beta-adrenoceptor ligands. In these and in previous experiments in our laboratory, all three ligands bound to single classes of homogeneous, noninteracting binding sites that gave straight lines on Scatchard analysis and Hill coefficients near 1 . Under such conditions, the use of two radioligand concentrations to determine antagonist binding seems reliable, because both binding points will be distributed along the same regression line. In the experiments with $\left[{ }^{3} \mathrm{H}\right]$ yohimbine, fat cells were incubated for $15 \mathrm{~min}$ with 5 and $20 \mathrm{nmol} / \mathrm{liter}$ of the radioligand in tracer experiments and from $0.3-20 \mathrm{nmol} / \mathrm{liter}$ in saturation experiments. Nonspecific binding was determined in parallel incubations with $10 \mu \mathrm{mol} / \mathrm{liter}$ of phentolamine present in the medium and was estimated at $\sim 40 \%$ of the total binding. The coefficient of variance (CV) between duplicates was $4 \%$ for specific binding of $\left[{ }^{3} \mathrm{H}\right]$ yohimbine. Fat cells were incubated for $60 \mathrm{~min}$ with 100 and $750 \mathrm{pmol} / \mathrm{liter}$ of ${ }^{125} \mathrm{ICYP}$ or for $15 \mathrm{~min}$ with 0.4 and $4 \mathrm{nmol} / \mathrm{liter}$ of $\left[{ }^{3} \mathrm{H}\right] \mathrm{CGP}$ in the beta-adrenoceptor tracer experiments, and with $15-750 \mathrm{pmol} / \mathrm{liter}$ of ${ }^{125} \mathrm{I}-\mathrm{CYP}$ in the saturation experiments. Nonspecific binding was determined from parallel incubations in the presence of $0.1 \mu \mathrm{mol} / \mathrm{liter}$ of propranolol and was $\sim 40$ and $20 \%$ of the total binding for ${ }^{125} \mathrm{I}-\mathrm{CYP}$ and ${ }^{3} \mathrm{H}-\mathrm{CGP}$, respectively. The CVs for specific binding were 9 and $8 \%$, respectively, for the two ligands in the beta-adrenoceptor assay.

In competitive experiments with unlabeled agonists, half of the amount of adipocytes mentioned above was incubated in a final volume of $0.5 \mathrm{ml}$ with $5 \mathrm{nmol} /$ liter of $\left[{ }^{3} \mathrm{H}\right]$ yohimbine for $15 \mathrm{~min}$ in the presence or absence of 8-14 different concentrations of clonidine ranging from $10^{-11}$ to $10^{-4} \mathrm{~mol} /$ liter. In the beta-receptor assay, 100 $\mathrm{pmol} / \mathrm{liter}$ of ${ }^{125} \mathrm{I}$-CYP was incubated as above, but for $60 \mathrm{~min}$ with or without 10 different concentrations of isoprenaline from $10^{-13}$ to $10^{-4}$ $\mathrm{mol} /$ liter. Nonspecific binding was determined at the highest concentration of $10^{-4} \mathrm{~mol} / \mathrm{liter}$ of clonidine and isoprenaline and was not different from nonspecific binding determined with antagonists. The displacement curves were always shallow. They were analyzed with a computer-assisted modeling technique (18), using nonlinear least square regression analysis, and were always significantly better fitted to

1. Abbreviations used in this paper: $\mathrm{CV}$, coefficient of variance; $\mathrm{ED}_{50}$, half-maximal effective dose; $\left[{ }^{3} \mathrm{H}\right] \mathrm{CGP},( \pm)-4$ (3-butylamino-2-hydroxypropoxy)-(5,7- $\left.{ }^{3} \mathrm{H}\right)$-benzimidazole-2-1-hydrochloride; ${ }^{125} \mathrm{ICYP},{ }^{125} \mathrm{I}-$ cyanopindolol; KRP, Krebs Ringer phosphate; PIA, phenyl-isopropyl-adenosine. a two-site model. From these data, the dissociation constants for highaffinity $\left(K_{\mathrm{h}}\right)$ and low-affinity $\left(K_{\mathrm{l}}\right)$ sites and their relative proportions $\left(R_{\mathrm{h}} / R_{\mathrm{l}}\right)$ were calculated. The results of methodological experiments revealed that the fit of the displacement curves did not significantly improve when more binding points were added to those used in the above-mentioned interval for clonidine or isoprenaline. In methodological experiments, two affinity states of the alpha ${ }_{2}$ - and the beta-receptor were documented. First, Hill coefficients for the displacement of radioligand binding were near one, using antagonists as competitor but were significantly lower when agonists were used. Secondly, in competition-inhibition experiments with plasma membrane, using radioactive antagonist and unlabeled agonist, the addition of GTP or GTP analogues converted receptors from a high- to a low-affinity state.

Lipolysis assay. The assay has been described in detail (15). Briefly, $\sim 2,000$ adipocytes were incubated in duplicate with air as the gas phase in $0.2 \mathrm{ml}$ of a medium of the same composition as above, except that the albumin concentration was increased to $40 \mathrm{~g} /$ liter. At the end of the incubation period an aliquot of the medium was taken for the determination of glycerol by a sensitive, kinetic bioluminescent method (15). In one set of experiments adipocytes were incubated for 2 $\mathrm{h}$ with various concentrations of $(a)$ noradrenaline (nonselective betaand alpha-adrenergic agonist) with and without $100 \mu \mathrm{mol} / \mathrm{liter}$ of yohimbine (alpha ${ }_{2}$-adrenergic antagonist), $(b)$ isoprenaline (nonselective beta-adrenergic agonist), (c) clonidine (selective alpha ${ }_{2}$ agonist), $(d)$ forskolin (direct activator of adenylate cyclase) (19), (e) enprofylline (selective inhibitor of phosphodiesterase) $(20),(f)$ dibutyryl-AMP (stimulator of protein kinase hormone-sensitive lipase) and $(g) \mathrm{N}^{6}-(1-$ 2-phenylisopropyl)-adenosine (adenosine deaminase-resistant adenosine agonist). In some experiments, the medium was supplemented with a maximum effective concentration $(1 \mathrm{U} / \mathrm{ml})$ of adenosine deaminase to remove endogenous adenosine entirely from the medium. In another set of experiments, the lipolytic effect of cholera toxin (which stimulates adenylate cyclase through ADP-ribosylation of the stimulatory GTP-binding protein $\mathrm{G}_{\mathrm{s}}[16]$ ) and pertussis toxin (which stimulates adenylate cyclase through ADP-ribosylation of the inhibitory GTP binding protein $G_{i}[21]$ ). Both toxins were activated for $60 \mathrm{~min}$ at $37^{\circ} \mathrm{C}$ with $9 \mathrm{~g} /$ liter $\mathrm{NaCl}, 25 \mu \mathrm{mol} /$ liter DTT, and $10 \mathrm{~g} /$ liter SDS before use. $2 \mathrm{~g} /$ liter Ovalbumin was also added to the cholera toxin activation solution. In preliminary experiments it was observed that both toxins stimulated lipolysis with a time lag of 90-120 min, and thereafter lipolysis was stimulated at a constant rate for at least $3 \mathrm{~h}$. The maximum effective concentration was $10 \mu \mathrm{g} / \mathrm{ml}$ for cholera toxin and 1 $\mu \mathrm{g} / \mathrm{ml}$ for pertussis toxin in the incubation medium. On the basis of these results fat cells were incubated for 2 and $3 \mathrm{~h}$ with or without 10 $\mu \mathrm{g} / \mathrm{ml}$ of cholera toxin or $1 \mu \mathrm{g} / \mathrm{ml}$ of pertussis toxin. In the toxin experiments, the difference in glycerol release between the second and third hours of incubation was calculated. The rate of glycerol release was linear for at least $4 \mathrm{~h}$ of incubation. The $\mathrm{CV}$ for glycerol release in the lipolysis experiments was $8 \%$. The responsiveness, i.e., maximal effect, on lipolysis was calculated as the difference between basal glycerol release and glycerol release at the maximum effective concentration of the lipolytic or the antilipolytic agent. The concentration of adrenergic agonist that produced a half-maximum effect $\left(\mathrm{ED}_{50}\right)$ was calculated from logistic conversion of the dose-effect curves as described previously (6).

Adipocyte measurements. The fat cell volume and the number of fat cells incubated were determined as described in detail previously (15).

Chemicals. Dialyzed BSA (fraction V) was purchased from the Armour Pharmaceutical Co. (Eastbourne, UK). $\left[{ }^{3} \mathrm{H}\right]$ Yohimbine $(85$ $\mathrm{Ci} / \mathrm{mmol})$ and ${ }^{125} \mathrm{I}-\mathrm{CYP}(2,200 \mathrm{Ci} / \mathrm{mmol})$ came from New England Nuclear Co. (Boston, MA). $\left[{ }^{3} \mathrm{H}\right] \mathrm{CGP}(40 \mathrm{Ci} / \mathrm{mmol})$ was purchased from Amersham International (Amersham, UK), and pertussis toxin was purchased from List Biological Laboratories (Campbell, CA). Propranolol was kindly donated by Hässle AB (Gothenburg, Sweden), phentolamine was donated by Ciba Geigy (Basle, Switzerland), and clonidine was donated by Boehringer-Ingelheim (Rhein, FDR). All other agents came from Sigma Chemical Co. (St. Louis, MO). 
Table I. Basal Lipolysis and Lipolytic Responsiveness of Catecholamines in Abdominal and Gluteal Sites

\begin{tabular}{lccccc}
\hline & \multicolumn{3}{c}{ Men } & & \multicolumn{2}{c}{ Women } \\
\cline { 2 - 3 } & Abdominal & Gluteal & Abdominal & Gluteal \\
\hline & & \multicolumn{2}{c}{$\mu$ mol/2 $h / 10^{7}$ cells } & \\
Basal lipolysis & $5.4 \pm 1(15)$ & $10.2 \pm 1.8^{*}(15)$ & $5.7 \pm 1.1(15)$ & $9.2 \pm 1.7^{*}(15)$ \\
Noradrenaline & $15.5 \pm 2.1^{\ddagger}(12)$ & $4.5 \pm 2.5(12)$ & & $20.5 \pm 2.3^{\ddagger}(11)$ & $2.0 \pm 1.3(11)$ \\
Noradrenaline plus yohimbine & $40.9 \pm 6(9)$ & $35.2 \pm 3(9)$ & $49.4 \pm 5(8)$ & $41.9 \pm 8(11)$ \\
Isoprenaline & $46.5 \pm 6(15)$ & $39.2 \pm 5(15)$ & $46.4 \pm 4(15)$ & $35.9 \pm 6(11)$ &
\end{tabular}

Lipolytic responsiveness was calculated for each individual as the glycerol release at maximum effective hormone concentration, minus basal glycerol release. Number of experiments are shown between brackets. Values are means \pm SE. ANOVA and the paired or unpaired $t$ test were used for statistical comparisons. The results are obtained from the same experiments that are described in Figs. 1, 3, and 4. * A significant difference at $P<0.02$ between the abdominal and gluteal sites; ${ }^{\ddagger}$ a significant difference $P<0.01$ between the abdominal and gluteal sites; ${ }^{\S}$ a significant difference $P<0.05$ between the sexes at the abdominal site.

Statistical methods. The values presented are the means \pm SEM. Regression analysis, two-way analysis of variance for repeated measures (ANOVA) and the paired or unpaired $t$ tests were used for statistical comparison of the results.

\section{Results}

Basal lipolysis and cellularity. The basal rate of lipolysis in gluteal adipocytes was almost twice that in abdominal adipocytes in both men and women in the absense of adenosine deaminase (Table I). However, when the buffer was supplemented with enzyme, there was no statistical difference in basal lipolysis rate between the regions (data not shown).

In females, adipocytes from the gluteal region were slightly larger than those from the abdominal region, the adipocyte volume being $675 \pm 43$ vs. $855 \pm 42 \mathrm{pl}, P<0.05$. Such differences were not observed in men $(691 \pm 85$ vs. $776 \pm 66 \mathrm{pl})$. There were no differences between men and women in the two regions as regards the basal lipolysis rate and fat cell size.

Noradrenaline-induced lipolysis. In both sexes noradrenaline induced a nearly 10-fold more pronounced lipolytic response in abdominal fat cells than in gluteal cells (Fig. 1 and Table I). The hormone stimulated the basal lipolysis rate at least four to fivefold in abdominal cells, but was almost inef- fective in gluteal cells. However, noradrenaline also had a significantly more pronounced effect $(P<0.05)$ in abdominal fat cells from females than in those from males, the maximum effect being $20.5 \pm 3.1$ vs. $15.5 \pm 3.1 \mu \mathrm{mol}$ glycerol $/ 2 \mathrm{~h} / 10^{7}$ cells, respectively. When adenosine deaminase was added to the incubation medium the basal rate of lipolysis increased by $50-100 \%$, but the regional and sex differences in noradrenaline-induced lipolysis were still observed (Fig. 1). Adenosine deaminase did not change the lipolytic effects of the other lipolytic agents used in this study. This indicates that adenosine has no major effects on stimulated lipolysis in our incubation system, and it confirms previous results from our laboratory using this incubation method (22). It is unlike other incubation methods where leakage of adenosine from human fat cells has marked effects on lipolysis (23).

Lipolytic effect of postreceptor acting agents. The mechanism behind the site and sex differences in noradrenaline-induced lipolysis may be located anywhere in the cascade of events that promote lipolysis after catecholamine stimulation. Therefore, the effects of agents that stimulate lipolysis at different postadrenoceptor steps were studied (Fig. 2). Surprisingly, the regional differences observed with noradrenaline-induced lipolysis were not found when postreceptor acting compounds were used. Thus, when lipolysis was stimulated with

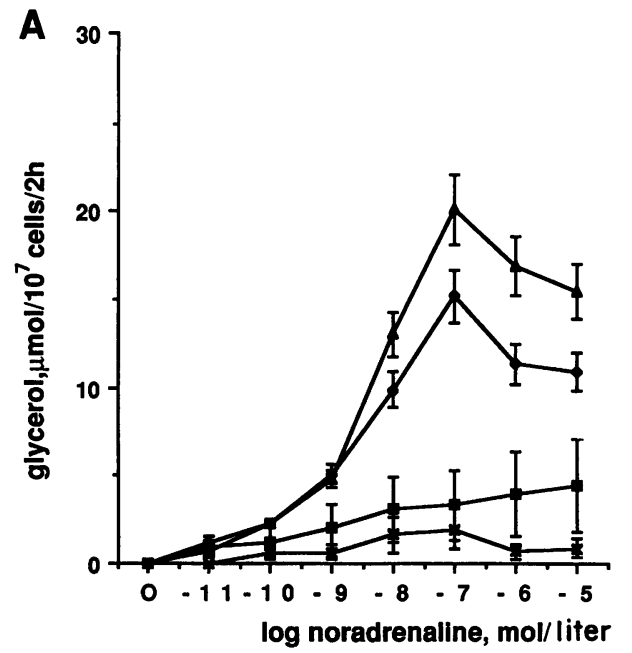

B

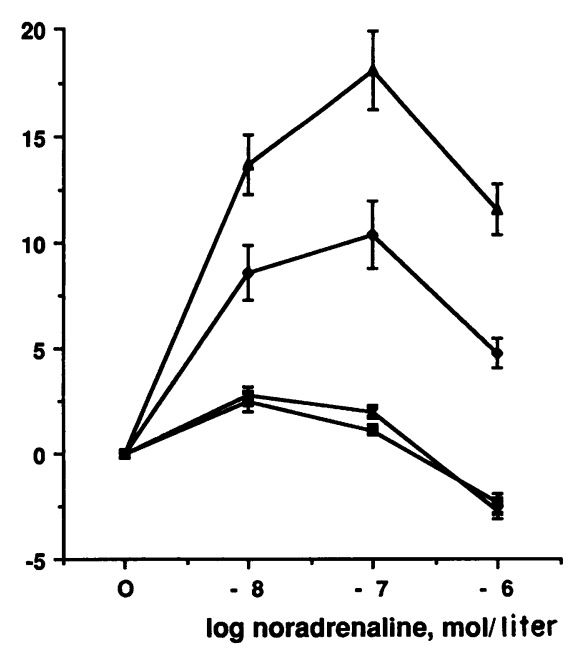

Figure 1. Noradrenaline-induced glycerol release in isolated adipocytes from 11 women and 12 men. Fat cells were obtained from the abdominal and gluteal regions and were incubated with increasing concentrations of noradrenaline $(A)$ without and $(B)$ with adenosine deaminase in the medium. Further details are given in Methods. The following symbols are used: abdominal cells from females ( $\mathbf{\Lambda}$; abdominal cells from males (४); gluteal cells from females (ם); and gluteal cells from males $(x)$. The results (means \pm SE) are expressed as agonist-induced glycerol release minus basal glycerol release. 

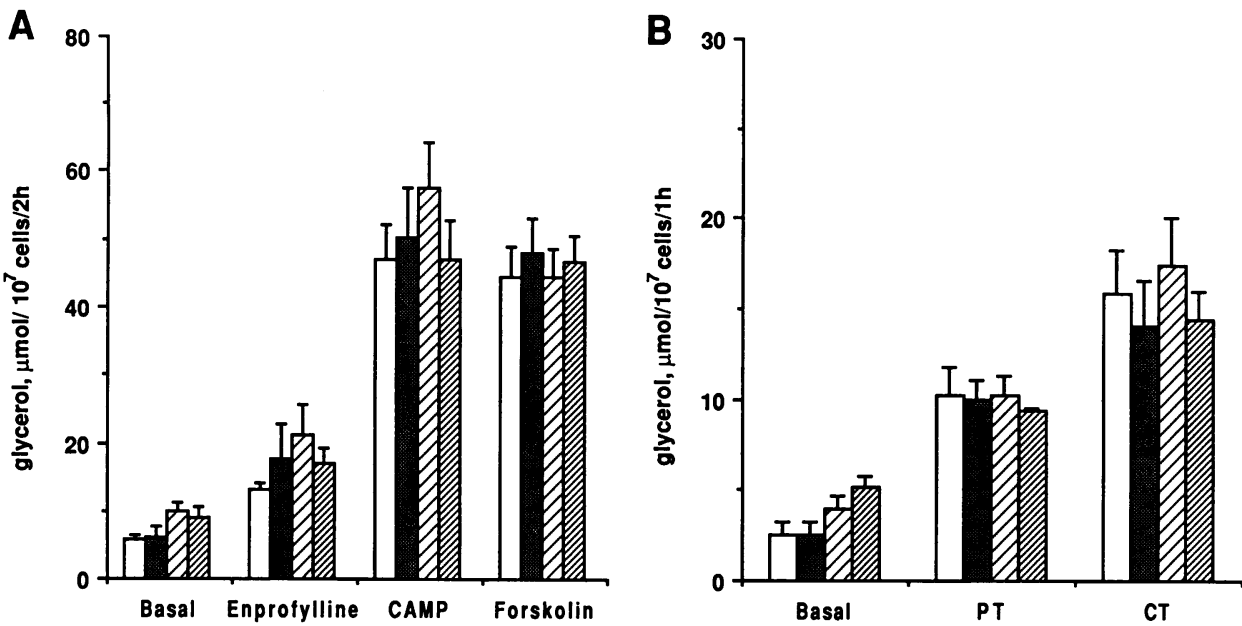

Figure 2. Stimulation of lipolysis at steps beyond the adrenoceptor level. Fat cells were obtained from 12 women and 11 men and were incubated with or without forskolin $\left(10^{-5}\right.$ $\mathrm{mol} / \mathrm{liter})$, enprofylline $\left(10^{-3} \mathrm{~mol} /\right.$ liter $)$, dibutyryl cAMP $\left(10^{-3} \mathrm{~mol} /\right.$ liter), cholera toxin (CT) $(10 \mu \mathrm{g} / \mathrm{ml})$ and pertussis toxin (PT) $(1 \mu \mathrm{g} / \mathrm{ml})$. Methodological experiments revealed that the concentrations of the different lipolytic agents used were maximum effective doses. $\square$, abdominal adipocytes from females; $⿴ 囗$, abdominal adipocytes from males; $\square$, gluteal female adipocytes; and $\mathrm{a}$, gluteal male adipocytes. Glycerol release values during the incubation period are shown (basal release has not been subtracted). See legend to Fig. 1 for further details.

increasing doses of forskolin $\left(10^{-9}-10^{-4} \mathrm{~mol} / \mathrm{liter}\right)$, enprofylline $\left(10^{-5}, 10^{-4} \mathrm{~mol} / \mathrm{liter}\right)$ or dibutyryl cAMP $\left(10^{-5}, 10^{-4} \mathrm{~mol} /\right.$ liter), which selectively act at the level of adenylate cyclase, phosphodiesterase, and protein kinase, respectively, the rates of glycerol release were similar in the abdominal and gluteal adipocytes of both sexes in all concentrations used (maximum effective doses charted in Fig. 2). Similarly, cholera toxin (acting on $G_{s}$ ) and pertussis toxin (acting at least in part on $G_{i}$ ) when added at maximum effective concentrations stimulated lipolysis to the same extent in the two regions in both groups. Thus, the mechanism responsible for the regional and sex differences in catecholamine-induced lipolysis is probably located at the adrenoceptor level. Fig. 2 shows that the rates of lipolysis using the toxins were somewhat lower than the rates using the other postreceptor acting drugs. However, the rates are not directly comparable, because the lipolysis experiments were performed under somewhat different incubation conditions.

Lipolytic effect of selective adrenergic agonists. Because the lipolytic effect of noradrenaline is a combination of both betaand alpha $_{2}$-adrenoceptor stimulation, selective agonists were used to distinguish between these effects. To explain the influence of the beta-adrenoceptor effect, the lipolytic effects of the pure beta agonist isoprenaline alone and of noradrenaline in the presence of a maximum effective concentration of yohimbine were studied. The dose-response curves of both isoprenaline and noradrenaline-yohimbine were significantly shifted more to the left in abdominal adipocytes than in gluteal adipocytes in both men and women (Fig. 3). The concentration at which a half-maximum effect $\left(E_{50}\right)$ was achieved was $10-20$ fold lower in the abdominal site for both agonists than in the gluteal sites (Table II). No differences between the sexes were observed within the two sites. This indicates an increased beta-adrenergic lipolytic sensitivity in the abdominal site in both sexes. The responses to isoprenaline were similar in all sites in both sexes (Table I).

To characterize the alpha $a_{2}$-adrenoceptor effect, the pure alpha $_{2}$-agonist clonidine was used. Clonidine inhibited basal lipolysis dose dependently (Fig. 4). At the maximum effective concentration, clonidine almost completely inhibited basal lipolysis in all four cell types. Because basal lipolysis was higher in abdominal adipocytes than in gluteal adipocytes the clonidine response was expressed as the percent inhibition of a maximum response. The inhibitory dose-response curve for clonidine was shifted far more to the right in fat cells from the abdominal site of females compared with that from the gluteal site, which indicated an increase in the alpha ${ }_{2}$-adrenoceptor antilipolytic sensitivity in the latter region (Fig. 4). No such difference was observed in men, where the antilipolytic effects of clonidine were identical at both sites. The sensitivity of the antilipolytic effect of clonidine, expressed as the half-maximal effective concentration ( $\mathrm{ED}_{50}$ ), was 40 times higher in the gluteal than in the abdominal cells of females (Table II).

When lipolysis was inhibited through the adenosine receptor with the adenosine deaminase-resistant adenosine analogue phenyl-isopropyl-adenosine (PIA), no differences between sex and site were observed (Fig. 4).

Antagonist radioligand binding. Because gluteal adipocytes were larger than abdominal adipocytes the binding data were expressed per cell surface area to correct for the difference in cell size.

The ${ }^{125}$ ICYP and $\left[{ }^{3} \mathrm{H}\right]$ CGP binding was significantly increased in abdominal adipocytes compared with gluteal adipocytes in both men and women. This was true when only two concentrations of radioligand were used (all subjects) as well as in the saturation experiments with ${ }^{125}$ ICYP binding (three male and three female subjects).

At 750 pmol, the ${ }^{125}$ ICYP binding was $12.8 \pm 2$ and $9.6 \pm .2$ amol $/ \mathrm{mm}^{2}$ in abdominal fat cells and $4.3 \pm 0.5$ and $5.8 \pm 1$ amol $/ \mathrm{mm}^{2}$ in gluteal fat cells in females and males, respectively $(P<0.01)$. If the results using the two different concentrations of each radioligand are representative of complete saturation experiments, they indicate that the number of betaadrenoceptor binding sites is twice as high in abdominal adipocytes than in gluteal adipocytes in both sexes. Moreover, the Scatchard analysis of complete saturation experiments with ${ }^{125}$ ICYP displayed straight and parallel lines for binding to both gluteal and abdominal cells (Fig. 5). This indicates, moreover, that there was no differences between the two sites in adrenoceptor affinity for the radioligand. The Scatchard data also showed that the maximum binding capacity of ${ }^{125}$ ICYP was almost twice as high in abdominal as in gluteal 

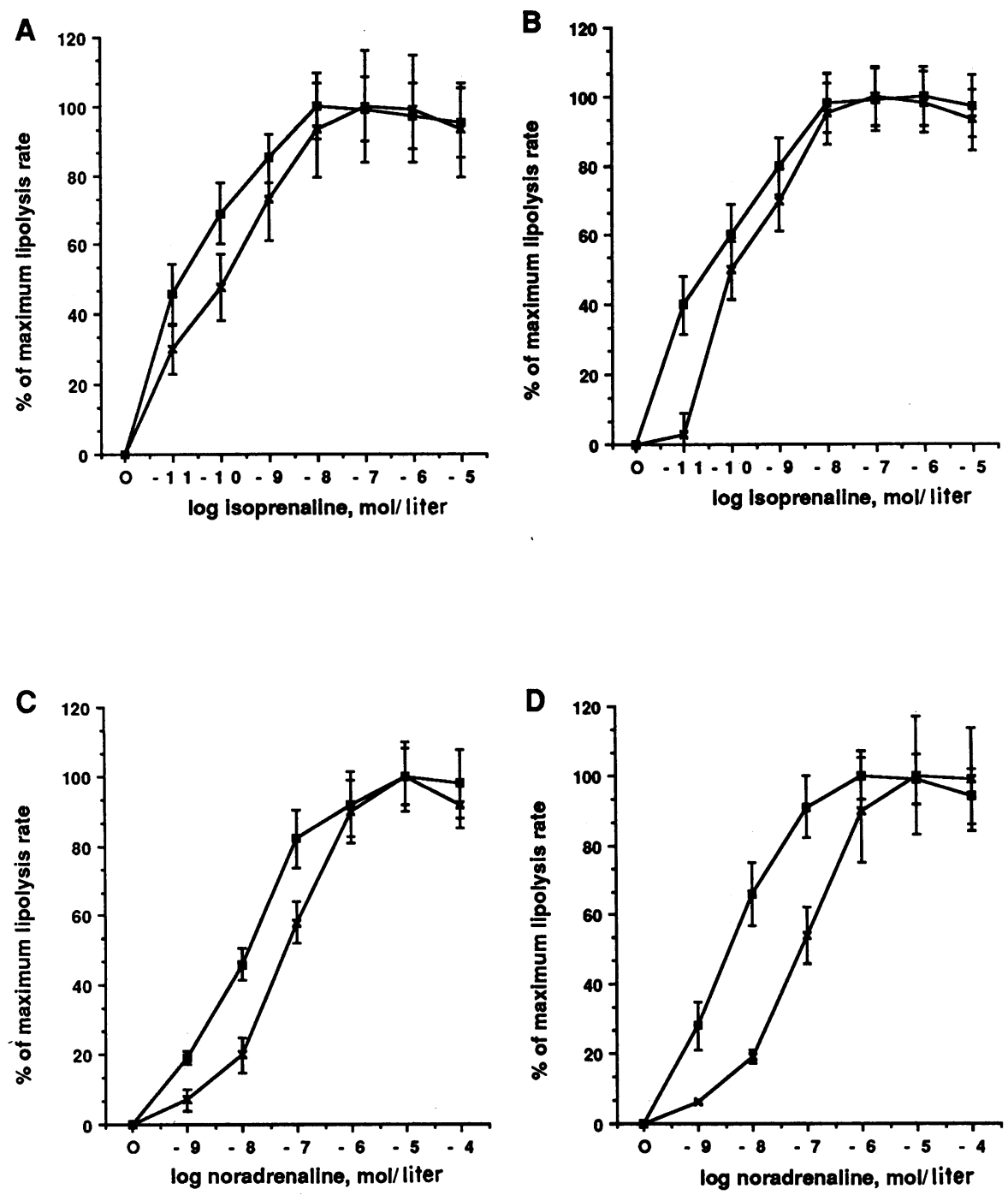

Figure 3. Lipolytic sensitivity to betaadrenergic agonists (isoprenaline and noradrenaline plus $100 \mu \mathrm{mol} /$ liter of yohimbine) in abdominal $(\square)$ and gluteal $(x)$ adipocytes from 15 men $(A$ and $C)$ and 15 women $(B$ and $D)$. The lipolytic effect was expressed as a percentage of the maximal response. For further details see legend to Fig. 1.

adipocytes of both sexes. Thus, there was a twofold difference between abdominal and gluteal cells in the number of betaadrenoceptors. The sex of the subject had no significant effect on beta-adrenoceptor binding. When all six saturation experiments (three males, three females) were statistically analyzed together, the beta-adrenoceptor density was significantly higher in abdominal than in gluteal adipocytes, being $145,000 \pm 29,000$ and $87,000 \pm 17,000$ receptors/cell, respectively $(P<0.01)$

The binding of the alpha ${ }_{2}$-receptor radioligand $\left[{ }^{3} \mathrm{H}\right]$ yohim- bine did not differ between the two sites in men and women (Fig. 6).

Competition-inhibition experiments with radioligands. Both isoprenaline and clonidine competed with ${ }^{125}$ ICYP and $\left[{ }^{3} \mathrm{H}\right]$ yohimbine, respectively, in a dose-dependent way, giving shallow and complex curves with low Hill coefficients that indicated a two-affinity state of the respective receptors. The displacement curves were analyzed with a computer-assisted modeling technique (18) using nonlinear least square regression analysis and was always significantly better fitted to a

Table II. Lipolytic Sensitivity

\begin{tabular}{|c|c|c|c|c|}
\hline & \multicolumn{2}{|c|}{ Men } & \multicolumn{2}{|c|}{ Women } \\
\hline & Abdominal & Gluteal & Abdominal & Gluteal \\
\hline Noradrenaline plus yohimbine (nmol/liter) & $8.3 \pm 5^{*}(9)$ & $117.5 \pm 106(9)$ & $3.8 \pm 1.1^{*}(8)$ & $166 \pm 106(8)$ \\
\hline Isoprenaline ( $p$ mol/liter) & $9.3 \pm 3.3^{*}(15)$ & $170 \pm 82(15)$ & $35.4 \pm 19^{\ddagger}(15)$ & $150 \pm 76(15)$ \\
\hline Clonidine (pmol/liter) & $200 \pm 112(9)$ & $304 \pm 143(9)$ & $1,300 \pm 123^{\ddagger}(8)$ & $33 \pm 11(8)$ \\
\hline
\end{tabular}

$\mathrm{ED}_{50}$ of various adrenergic agonists in abdominal and gluteal sites. The $\mathrm{ED}_{50}$ values were derived from logistic conversion of the corresponding dose-response curve for each individual. The values are the means \pm SE. Two-way ANOVA for repeated measures was used for statistical comparisons. See legend to Table I for further details. ${ }^{*}$ Significant difference $P<0.01$ from the corresponding value for the gluteal site; ${ }^{\ddagger} P$ $<0.05$. 

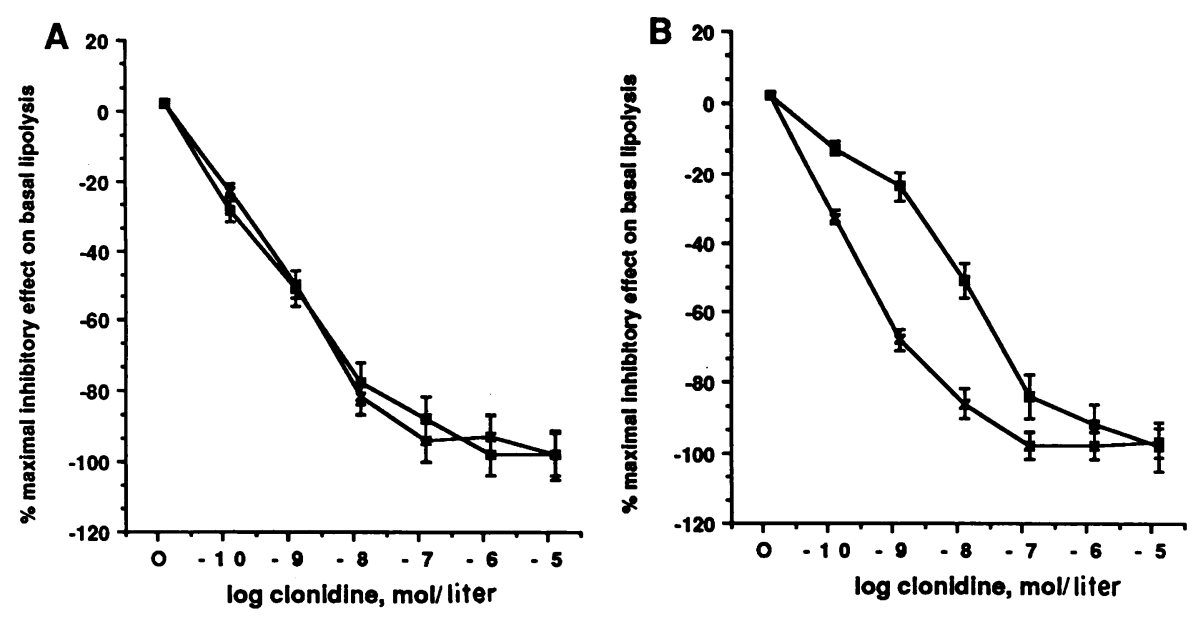

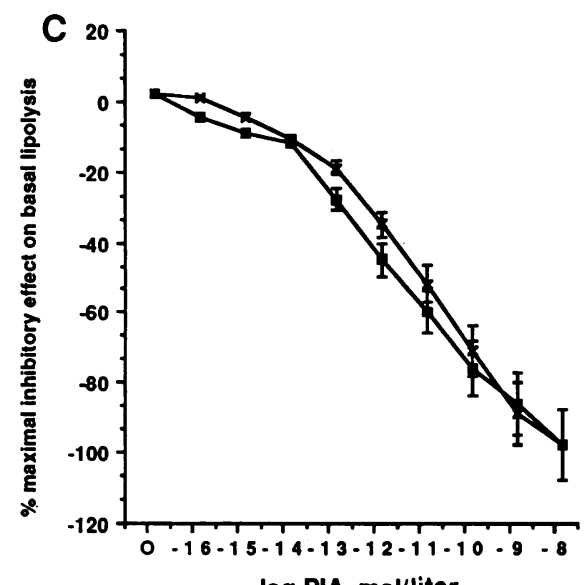

$\log \mathrm{PIA}$, mol/liter

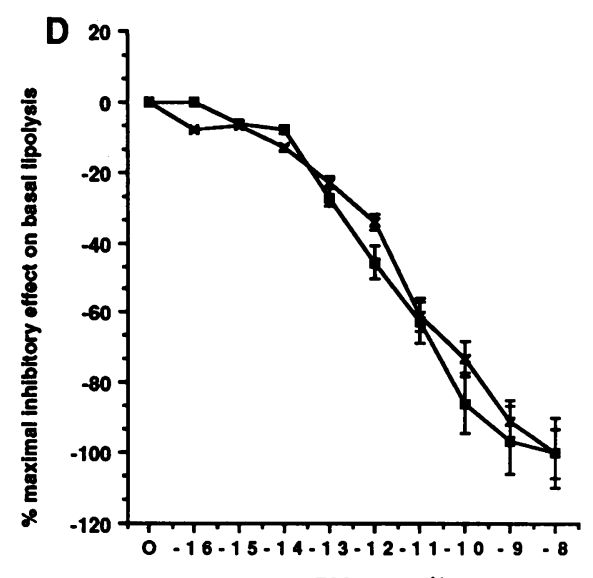

$\log$ PIA, mol/liter
Figure 4. Antilipolytic effect of the alpha 2 adrenergic agonist clonidine and the adenosine agonist PIA in abdominal ( $\square$ ) and gluteal $(x)$ adipocytes from 10 men $(A$ and $C)$ and 12 women $(B$ and $D)$. In these experiments, adenosine deaminase was added to the incubation medium to remove endogenous adenosine. The antilipolytic effect was expressed as a percentage of the maximal inhibitory effect on basal lipolysis. For further details see legend to Fig. 1. two-site model. From these data the dissociation constants for high- $\left(K_{\mathrm{h}}\right)$ and low-affinity $\left(K_{\mathrm{l}}\right)$ sites and their relative proportions $\left(R_{\mathrm{h}} / R_{\mathrm{l}}\right)$ were calculated and are presented in Table III. About $40 \%$ of the beta-receptors were in the high-affinity state in both regions in both males and females. Moreover, the affinity constants for the beta receptor did not differ between the sexes or the regions. Half of the alpha $a_{2}$ receptors were in the high-affinity state, no significant difference in this respect being observed between the sexes or the regions. However, the affinity of clonidine for the alpha a $_{2}$ receptor in abdominal fat cells of women was markedly and significantly lower than in the gluteal site. This was true of both the high- $(50$-fold difference) and the low-affinity (10-fold difference) states of the alpha $_{2}$ receptor $\left(K_{\mathrm{h}}, P<0.05 ; K_{1}, P<0.01\right)$.

Role of denominator in the results. Lipolysis was expressed per cell and antagonist binding was expressed per cell surface area. The results were about the same when cell number was used as the denominator in the latter experiments and when the lipolysis experiments were expressed per cell surface area.

\section{Discussion}

Site variations in fat cell lipolysis may play a role in the development of different regional forms of obesity. This study deals with mechanisms underlying the regional differences in the lipolytic effects of catecholamines. Metabolic studies with agents acting at selective steps in lipolysis, as well as radioligand experiments with intact cells, were used for this purpose. The basal rate of glycerol release was slightly but significantly higher in gluteal than in abdominal adipocytes. This could in part be explained by a slight larger adipocyte size in the gluteal region because the basal lipolysis rate has been shown to be positively correlated to adipocyte volume (24). As indicated by the results with adenosine deaminase, small differences in leakage of adenosine between gluteal and abdominal adipocytes may also play a role. However, little is known about the factors governing basal glycerol release from isolated adipocytes in vitro and the biological significance of this variation. Moreover, this small variation in the basal rate did not influence upon the results of the stimulated lipolysis experiments, various absolute or net glycerol release was considered. No correlation was found between basal lipolysis rate and beta- or alpha $_{2}$-adrenergic sensitivity using semilogistic plotting.

In accordance with previous findings (1-5), fat cells from the abdominal site were found to be much more responsive than gluteal cells to the lipolytic effect of catecholamines. This difference was observed in both sexes, but it was more pronounced in females than in males. The latter may partly ex- 

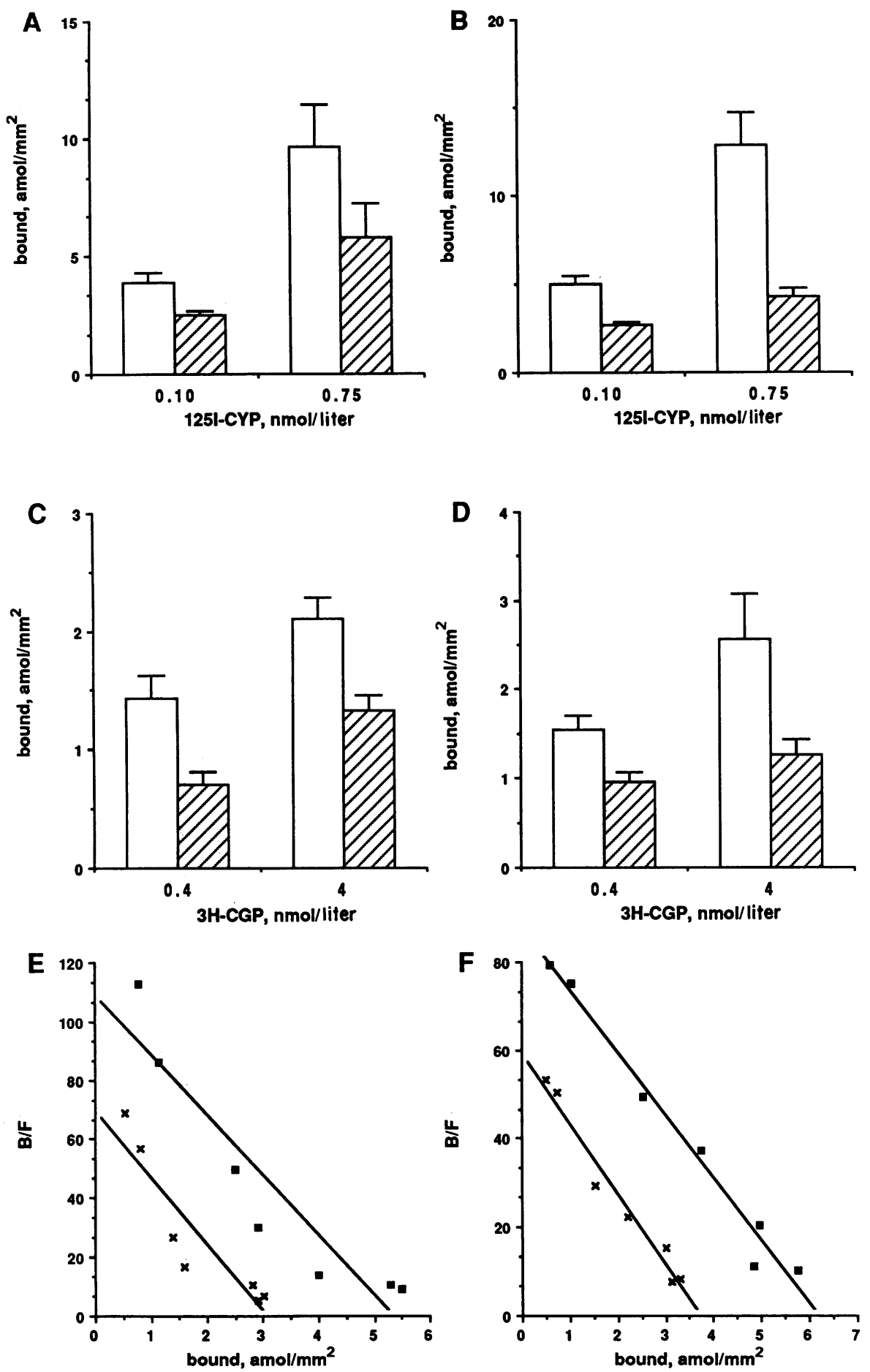

Figure 5. Specific binding of radioactive adrenoceptor beta-antagonists. (Top and middle) Fat cells from the abdominal ( $\square$ ) and gluteal ( $($ a) regions of 19 men $(A$ and $C)$ and 20 women $(B$ and $D$ ) were incubated with 100 and $750 \mathrm{pmol} / \mathrm{liter}$ of ${ }^{125} \mathrm{ICYP}$ or 0.4 and $4 \mathrm{nmol} /$ liter of $\left[{ }^{3} \mathrm{H}\right] \mathrm{CGP}$, as described in the text. (Bottom) Scatchard analyses of complete saturation experiments with ${ }^{125} \mathrm{I}-\mathrm{CYP}$ binding. In the latter experiments fat cells from the abdominal $(\boldsymbol{\theta})$ and gluteal $(x)$ regions of $(E)$ three men and $(F)$ three women were used. Values are means $\pm S E$.

plain why the difference in fat cell volume between the regions was more pronounced in women than in men. However, it must be noted that other factors, such as the triglyceride synthesis rate, also may govern adipocyte volume. The data with noradrenaline suggest also that sex factors are involved in the modulation of catecholamine action in fat cells from different regions. As human adipocytes possess both stimulating beta adrenoceptors and inhibiting alpha $a_{2}$ adrenoceptors, the observed regional difference in catecholamine action may be due either to an increased beta- or a decreased alpha ${ }_{2}$-adrenergic effect on lipolysis, or to both. In theory, any step in lipolysis activation from the receptor molecules to hormone-sensitive lipase may be responsible for the observed site variations in catecholamine action (25). However, when the most distal part of the chain, the protein-kinase-lipase complex, was stimulated the lipolytic difference between site and sex was completely abolished. Furthermore, stimulation of lipolysis at the level of phosphodiesterase, adenylate cyclase, or $G$ proteins resulted in an acceleration in glycerol release to similar rates in both regions in both sexes. Thus, the mechanisms responsible for regional differences in catecholamine-induced lipolysis is probably localized at the adrenoceptor level. 

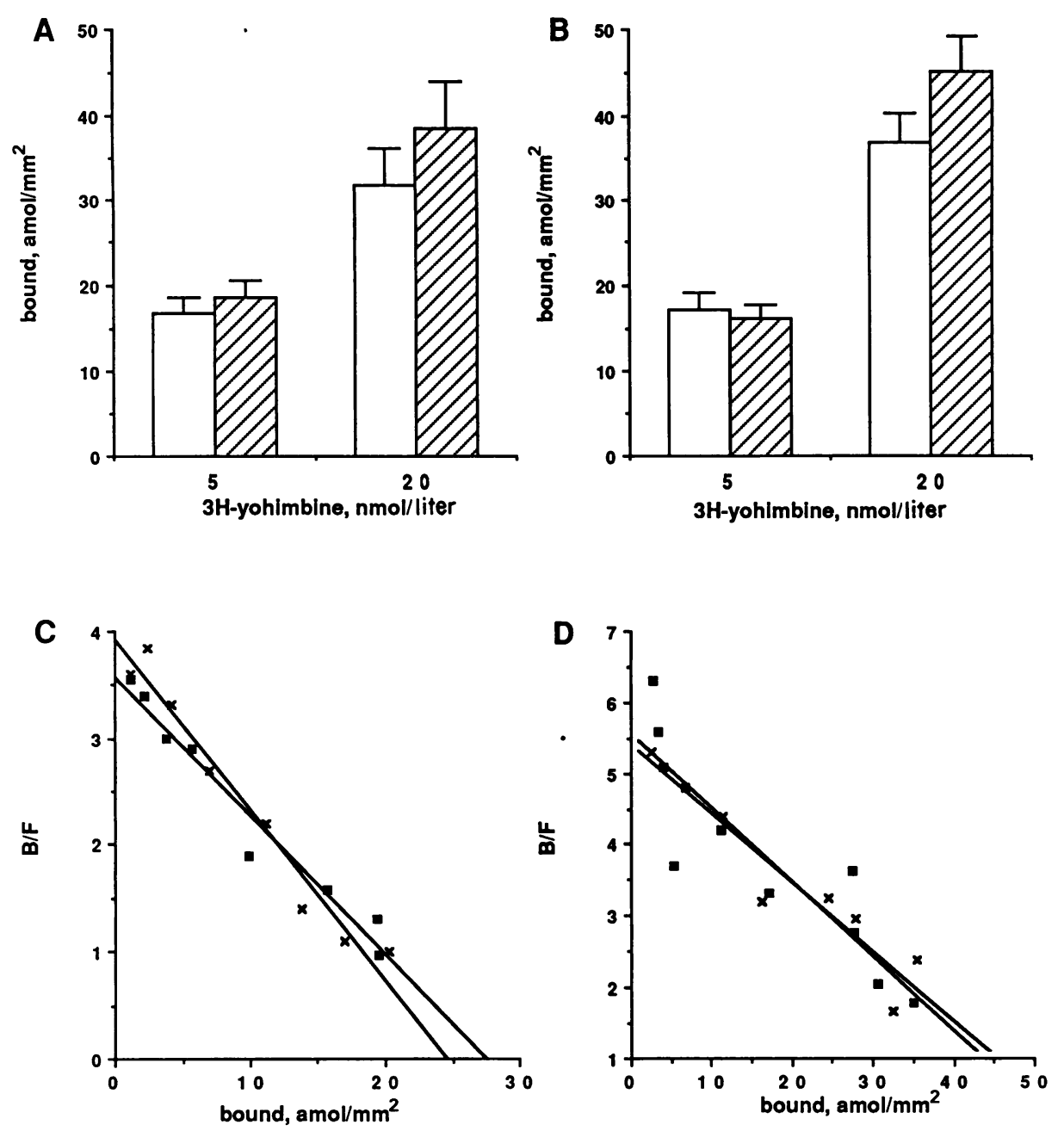

Figure 6. Specific binding of a radioactive adrenoceptor alpha ${ }_{2}$-antagonist. (Top) Fat cells from the abdominal and gluteal regions of $(A) 20$ men and $(B)$ 18 women were incubated with 5 and $20 \mathrm{nmol} /$ liter of $\left[{ }^{3} \mathrm{H}\right]$ yohimbine, as described in the text. (Bottom) Scatchard analyses of complete saturation experiments of $\left[{ }^{3} \mathrm{H}\right]$ yohimbine binding. In the latter experiments, fat cells from the abdominal and gluteal regions of $(C)$ three men and $(D)$ three women were used. See legend to Fig. 5 for further details.

In both sexes, there was a 10 - to 20 -fold increase in sensitivity in the abdominal site to the beta agonist isoprenaline and noradrenaline in combination with yohimbine. This indicates a much greater beta-adrenergic sensitivity in the abdominal fat cells than in gluteal cells in both sexes. Previous studies of obese subjects have also reported an increase in beta-adrenergic sensitivity in adipocytes from the abdominal site than in the femoral or the gluteal site $(5,26)$. The present findings may explain the mechanisms underlying this difference. There is evidence of a nonlinear relationship between beta-adrenoceptor occupancy and lipolysis in fat cells; only a fraction of the receptors need to be occupied in order to obtain a full response $(27,28)$. Thus, the increase in beta-adrenergic sensitivity in the abdomen may be explained by an increase in number and or an enhanced affinity of the beta receptor. The competition-inhibition experiments between ${ }^{125} \mathrm{I}-\mathrm{CYP}$ and isoprenaline revealed similar $K_{\mathrm{d}}$ values of both the high- and low-affinity states of the beta receptor in all sites. Furthermore, the relative proportions of high- and low-affinity binding sites did not differ between the adipose regions. However, the antagonist binding using two different beta-adrenergic antagonists as radioligands, the lipophilic ${ }^{125} \mathrm{I}-\mathrm{CYP}$, which labels cell surface and sequestered binding sites, and the hydrophilic ${ }^{3} \mathrm{H}-\mathrm{CGP}$, which labels cell surface binding sites, uniformly showed twice as many beta-adrenergic binding sites in the abdominal adipocytes as in the femoral adipocytes. In previous studies we ob- served that inactivation of $\sim 50 \%$ of the beta adrenoceptors was followed by a $>10$-fold reduction of the beta-adrenoceptor sensitivity in isolated human fat cells (28). Thus, the observed increase in beta-adrenergic lipolytic sensitivity in abdominal adipocytes accords with the observed increase in the total number of beta-adrenoceptors in this site. Using $\left[{ }^{3} \mathrm{H}\right] \mathrm{di}$ hydroalprenolol as radioligand, Lafontan and co-workers (26) found no significant difference between the omental, the abdominal, and femoral regions in the number of binding sites in adipocyte membranes. However, the discrepancy between their results and ours may be methodological. In the earlier investigation, the femoral and abdominal fat biopsies were obtained from different individuals, whereas in our study the fat cells were obtained from two regions in the same subjects. Furthermore, broken cells were investigated in Lafontan's study. It is well known that adrenoceptor binding properties may be artificially altered during preparation of the membranes (29). Finally, we investigated nonobese subjects, whereas Lafontan and co-workers studied obese ones.

It was also observed in this study that females exhibit a lower antilipolytic sensitivity to clonidine in the abdominal adipocytes as than in the gluteal adipocytes; no such difference was observed in males. This reduction in the alpha ${ }_{2}$-adrenergic effect in abdominal fat cells may explain why the lipolytic effect of noradrenaline was more pronounced in the abdominal fat cells of females than in those of males. The data also 
Table III. Beta- and Alpha $a_{2}$-Adrenoceptor Affinities for Isoprenaline and Clonidine, Respectively, and the Proportion of Receptors in a High-Affinity State in the Abdominal and Gluteal Sites

\begin{tabular}{lcclll}
\hline & \multicolumn{2}{c}{ Men } & & \multicolumn{2}{c}{ Women } \\
\cline { 2 - 3 } \cline { 5 - 6 } \cline { 5 - 6 } & Abdominal & Gluteal & & Abdominal & Gluteal \\
\hline Beta sites ( $\left.{ }^{125} \mathrm{I}-\mathrm{CYP}\right)$ & & & & \\
$\mathrm{K}_{\mathrm{h}}($ nmol/liter $)$ & $5.0 \pm 4.8$ & $1.7 \pm 4.3$ & & $2.5 \pm 9.3$ & $2.5 \pm 5.4$ \\
$\mathrm{~K}_{\mathrm{I}}(\mu$ mol/liter $)$ & $4.0 \pm 1.4$ & $5.6 \pm 2.2$ & & $3.0 \pm 2$ & $3.8 \pm 6.4$ \\
$\% R_{\mathrm{h}}$ & $39 \pm 3$ & $40 \pm 5$ & & $37 \pm 4$ & $42 \pm 6$ \\
Alpha sites & & & & \\
$\quad\left(\left[{ }^{3} \mathrm{H}\right]\right.$ yohimbine $)$ & & & & \\
$\mathrm{K}_{\mathrm{h}}($ nmol/liter $)$ & $8.9 \pm 3.2$ & $4.6 \pm 2$ & & $56.2 \pm 4.6^{*}$ & $1.2 \pm 4.1$ \\
$\mathrm{~K}_{\mathrm{l}}(\mu$ mol/liter $)$ & $2.6 \pm 1.6$ & $3.3 \pm 2.9$ & & $69.7 \pm 7.6^{\ddagger}$ & $7.1 \pm 3.4$ \\
$\% R_{\mathrm{h}}$ & $54 \pm 7$ & $46 \pm 6$ & & $50 \pm 5$ & $51 \pm 6$ \\
& & & &
\end{tabular}

Results of competition-inhibition binding experiments analyzed by a computer-iterative curve fitting to a model for two classes of noninteracting binding sites which give the dissociation constants for high$\left(K_{\mathrm{h}}\right)$ and low- $\left(K_{\mathrm{l}}\right)$ affinity states and the percentage of receptors in a high-affinity state. Adipocytes were obtained from the abdominal and gluteal regions of 11 men and 9 women and incubated with ${ }^{125} \mathrm{I}$ cyanopindolol or ${ }^{3} \mathrm{H}$-yohimbine as described in the text. All values are the means $\pm S E$. Two-way ANOVA for repeated measures was used for statistical comparison.

* A significant difference $P<0.05$ from the corresponding value at all other sites; ${ }^{\ddagger}$ a significant difference $P<0.01$ from the corresponding value at all other sites.

suggest that the alpha ${ }_{2}$ effect of catecholamines in fat cells may be governed by sex factors. Leibel and Hirsch (5) also found more alpha activity in the abdominal cells of obese men than in those of obese women. Furthermore, Lafontan and coworkers (26) found that the sensitivity to clonidine was lower in the abdominal cells than in the femoral cells of obese women.

These data may clarify the mechanisms underlying the regional differences in alpha ${ }_{2}$ effects in women. They may be located at the alpha $a_{2}$-receptor molecule or at the level of $G_{i}$, or some other G-protein which couples the receptor to the adenylate cyclase (30), and acting antilipolytic in human fat cells (31). Both adenosine receptors and alpha $_{2}$-receptors are coupled to adenylate cyclase through a common $\mathrm{G}_{\mathrm{i}}$-protein located in the plasma membrane. However, adenosine receptor sensitivity, as judged by data obtained with PIA, was similar in abdominal and gluteal fat cells, indicating indirectly an unaltered $G_{i}$ signal system between these two depots. This is in agreement with the findings of Stoneham and co-workers (32). Moreover, there were no regional differences in the lipolytic effects of pertussis toxin, which mainly acts on $G_{i}(30)$, although small differences in the abundance of the $G_{i}$-protein cannot be excluded, as only one maximum effective concentration of pertussis toxin was used. In view of these findings, it is unlikely that the $\mathrm{G}$ proteins alone act as main modulators of clonidine sensitivity. Furthermore, the number of alpha ${ }_{2}-$ adrenergic binding sites (judged by $\left[{ }^{3} \mathrm{H}\right]$ yohimbine binding) was not different between abdominal and gluteal cells. On the other hand, competition-inhibition experiments with clonidine revealed a marked decrease in the affinity properties of the alpha ${ }_{2}$ adrenoceptor of abdominal fat cells in females. It should be noted that the regional differences in clonidine antilipolytic sensitivity and receptor affinity were in the same order of magnitude. Thus, $\mathrm{ED}_{50}$ and $K_{\mathrm{d}}$ for the high-affinity state of the receptor differed between abdominal and gluteal cells by factors of 40 and 50 , respectively. The lower alpha $a_{2}$ adrenergic sensitivity of the latter adipocytes in women can be explained by a reduced affinity of the alpha ${ }_{2}$ receptor for catecholamines. Whether the latter is due to variations in the adrenoceptor molecule or in the coupling between the hormone-receptor complex and $G_{i}$, which modulates receptor affinity (30) is not known at present. Unfortunately the methods used to study such events require excessively large amounts of adipose tissue. Lafontan and co-workers (26) found no difference between the abdominal and the femoral sites regarding receptor number and agonist affinity of the alpha ${ }_{2}$ adrenoceptor. The differences between their methods and ours, as discussed above, may explain the discrepancies in the findings concerning alpha $a_{2}$-receptor affinity.

The major determinant of regional differences in catecholamine action on lipolysis in fat cells seems to be beta-adrenergic sensitivity, which is due to variations in the total number of beta-adrenergic receptors. In women, variations in the affinity properties of the alpha ${ }_{2}$ adrenoceptor play an additional role. The latter may explain why regional variations in lipolytic activity are more apparent in women than in men. These may be some of the potential molecular mechanisms for the regional differences in fat distribution between men and women and for the development of different types of obesity, although further studies are needed to clarify the in vivo significance of these findings.

\section{Acknowledgments}

This study was supported by grants from the Swedish Medical Research Council (grant 19X-01034), the Swedish Diabetes Association, the Karolinska Institute, the Swedish Medical Association, the Swedish Athletic Association and the Hoechst, Folksam, Osterman, Wiberg, Nilsson, Nordic Insulin, Groschinsky, Stohne, and Old Female Servants foundations.

\section{References}

1. Kather, H., K. Zöllig, B. Simon, and G. Schlierf. 1977. Human fat cell adenylate cyclase: regional differences in adrenaline responsiveness. Eur. J. Clin. Invest. 7:595-597.

2. Smith, U., J. Hammersten, P. Björntorp, and J. G. Kral. 1979. Regional differences and effect of weight reduction on human fat cell metabolism. Eur. J. Clin. Invest. 9:327-332.

3. Lafontan, M., L. Dang-Tran, and M. Berlan. 1979. Alphaadrenergic antilipolytic effect of adrenaline in human fat cells of the thigh: comparison with adrenaline responsiveness of different fat deposits. Eur. J. Clin. Invest. 9:261-266.

4. Östman, J., P. Arner, P. Engfeldt, and L. Kager. 1979. Regional differences in the control of lipolysis in human adipose tissue. Metab. Clin. Exp. 28:1198-1205.

5. Leibel, R., and J. Hirsch. 1987. Site- and sex-related difference in adrenoceptor status of human adipose tissue. J. Clin. Endocrinol. \& Metab. 64:1205-1210.

6. Östman, J., P. Arner, H. Kimura, H. Wahrenberg, and P. Engfeldt. 1984. Influence of fasting on lipolytic response to adrenergic agonists and adrenergic receptors in subcutaneous adipocytes. Eur. $J$. Clin. Invest. 14:383-391.

7. Larsson, B., K. Svärdsudd, L. Welin, L. Wilhelmsen, P. Björntorp, and G. Tibblin. 1984. Abdominal adipose tissue distribution, 
obesity, and risk of cardiovascular disease and death: 13 year follow-up of participants in the study of men born in 1913. Br. Med. J. 288:1401-1404.

8. Lapidus, L., C. Bengtsson, B. Larsson, K. Pennert, E. Rybo, and L. Sjöström. 1984. Distribution of adipose tissue and risk of cardiovascular disease and death: a 12 year follow-up of participants in the population study of women in Gothenburg, Sweden. Br. Med. J. 289:1257-1261.

9. Krotkiewski, M., P. Björntorp, L. Sjöström, and U. Smith. 1983. Impact of obesity on metabolism in men and women: importance of regional adipose tissue distribution. J. Clin. Invest. 72:1150-1162.

10. Evans, D., R. Hoffmann, R. Kalkhoff, and A. Kissebah. 1983. Relationship of androgenic activity to body fat topography, fat cell morphology, and metabolic aberrations in pre-menopausal women. $J$. Clin. Endocrinol. \& Metab. 57:304-310.

11. Marcus, C., H. Ehrén, P. Bolme, and P. Arner. 1988. Regulation of lipolysis during the neonatal period. Importance of thyrotropin. J. Clin. Invest. 82:1793-1797.

12. Östman, J., and S. Efendic. 1970. Catecholamines and metabolism of human adipose tissue. II. Effect of isopropylnoradrenaline and adrenergic blocking agents on lipolysis in human omental adipose tissue in vitro. Acta Med. Scand. 187:471-476.

13. Burns, T. W., and P. E. Langley. 1970. Lipolysis by human adipose tissue: the role of cyclic $3^{\prime}, 5^{\prime}$-adenosine monophosphate and adrenergic receptor sites. J. Lab. Clin. Med. 75:983-987.

14. Arner, P., O. Arner, and J. Östman. 1973. The effect of local anesthetic agents on lipolysis by human adipose tissue. Life Sci. 13:161-169.

15. Björkhem, I., P. Arner, A. Thore, and J. Östman. 1981. Sensitive kinetic bioluminescent assay of glycerol release from human fat cells. J. Lipid Res. 22:1142-1147.

16. Rodbell, M. 1964. Metabolism of isolated fat cells. I. Effects of hormones on glucose metabolism and lipolysis. J. Biol. Chem. 239:375-380.

17. Engfeldt, P., P. Arner, H. Kimura, H. Wahrenberg, and J. Östman. 1984. Determination of adrenoceptors of alpha 2 -subtype on isolated human fat cells. Scand. J. Clin. Lab. Invest. 14:383-391.

18. Munson, P. J., and D. A. Rodbard. 1980. A versatile computerized approach for characterization of ligand binding systems. Anal. Biochem. 107:220-239.

19. Seamon, K. B., W. Padgett, and J. W. Daly. 1981. Forskolin: a unique diterpene activator of adenylate cyclase in membranes and intact cells. Proc. Natl. Acad. Sci. USA. 78:3363-3367.

20. Fredholm, B. B., and E. Lindgren. 1983. The effect of alkylxanthines and other phosphodiesterase inhibitors on adenosine-mediated decrease in lipolysis and cyclic AMP accumulation in rat fat cells. Acta Pharmacol. Toxicol. 54:64-69.

21. Gilman, A. G. 1984. Guanine nucleotide-binding regulatory proteins and dual control of adenylate cyclase. J. Clin. Invest. 73:1-4.

22. Marcus, C., B. Karpe, P. Bolme, T. Sonnefeld, and P. Arner. 1987. Changes in catecholamine-induced lipolysis in isolated human fat cells during the first year of life. J. Clin. Invest. 79:1812-1818.

23. Kather, H., W. Bieger, G. Michel, K. Aktories, and K. H. Jakobs. 1985 . Human fat cell lipolysis is primarily regulated by inhibitory modulators acting through distinct mechanisms. J. Clin. Invest. 76:1559-1565.

24. Arner, P., and J. Östman. 1978. Relationship between the tissue level of cyclic AMP and the fat cell size of human adipose tissue. $J$. Lipid Res. 19:613-617.

25. Fain, J. N., and J. A. Garcia-Sainz. 1983. Adrenergic regulation of adipocyte metabolism. J. Lipid Res. 24:945-966.

26. Mauriege, P., J. Galitzky, M. Berlan, and M. Lafontan. 1987. Heterogeneous distribution of beta- and alpha ${ }_{2}$-adrenoceptor binding sites in human fat cells from various fat deposits: functional consequences. Eur. J. Clin. Invest. 17:156-165.

27. Lacasa, D., B. Agli, and Y. Giudicelli. 1984. "Spare" betaadrenergic receptors on rat white adipocyte membranes. Biochem. Int. 9:187-199.

28. Arner, P., J. Hellmér, J. Östman, and P. Engfeldt. 1988. Adrenoceptor occupancy in isolated human fat cells and its relationship with the lipolysis rate. Eur. J. Pharmacol. 146:45-53.

29. Porzig, H. 1982. Are there differences in the beta-receptor-adenylate cyclase system of fragmented membranes and living cells? Trends Pharmacol. Sci. 3:75-78.

30. Gilman, A. G. 1987. G-proteins: transducers or receptor-generated signals. Annu. Rev. Biochem. 56:615-649.

31. Lönnqvist, F., A. Wennlund, and P. Arner. 1989. Antilipolytic effects of insulin and adenylate cyclase inhibitors on isolated human fat cells. Int. J. Obesity. 13:137-146.

32. Stoneham, S., T. Kiviluoto, L. Keso, and J. Ohisalo. 1988. Adenosine and the regional differences in adipose tissue metabolism in women. Acta Endocrinol. 118:327-331. 